\title{
Impact of social stratification on child development and learning
}

\begin{abstract}
Social class or socioeconomic status greatly impacts child development and student achievement outcomes. It is well documented in educational and child development research that there is a significant achievement gap between children of economically stable backgrounds and economically disadvantaged environments. This article is a wholistic review of the available research from educational and developmental standpoints to provide an in-depth understanding of the struggles faced by children living in poverty. Research thus far has been reactionary to development in impoverished circumstances, this article proposes further research is needed to effectively understand the developmental milestones which may protect impoverished children and predict achievement from the serious hazards of growing up in poverty.
\end{abstract}

Keywords: social stratification, poverty, academic achievement, achievement gap, science achievement, curriculum, instruction, socioeconomic status, economics, biology, psychology, sociology
Special Issue - 2018

\author{
Maci Alexandra Hebert \\ Capella University, United States of America
}

Correspondence: Maci Alexandra Hebert, PhD Candidate Curriculum and Instruction, Capella University, 59I Westbrook Street South Portland ME 04I06,

Email Msherp7@capellauniversity.edu

Received: November 29, 2018 | Published: December 31, 2018

\section{Introduction}

Social stratification or socioeconomic status has created a societal phenomenon where those with greater economic resources have access to more opportunities than those of lesser financial means. ${ }^{1,2}$ Research has identified that those with more opportunities succeed at higher levels in academia than students on lower levels of the classbased system. ${ }^{3}$ This understanding of the educational achievement gap between classes has created a wealth of research with which to investigate the impact of and potentially rectify factors for wealth disparity in education. Educational practitioners and researchers alike have long asserted, the ethical imperative of education is to help all students achieve at high levels. ${ }^{4}$ Therefore, educational researchers have extensively sought to comprehend the achievement gap and how poverty impacts school performance. ${ }^{3,5-9}$ The field of curriculum and instruction is vast and all inclusive. Education and curriculum and instruction is an industry of serving, motivating and educating human individuals, the field incorporates and investigates through the perspectives of economics, biology, psychology and sociology. ${ }^{4}$ This has led to many diverse perspectives from which to explore and understand the academic achievement gap of impoverished students. Following the theory of Maslow's hierarchy of needs, researchers have identified students of disadvantaged backgrounds are less likely to have their basic needs met such as food, shelter, water, and safety. ${ }^{10}$ These students then attend school more concerned with their own need for food and safety; they are subsequently unable to be motivated by educational promises such as self-fulfillment., ${ }^{71-12}$

Researchers have also explored the impact of school and social programs to reduce poverty-based phenomena such as food insecurity. ${ }^{2,12}$ Despite gains made when schools adopt meal programs, economically disadvantaged students continue to underperform when compared with students of economically stable environments. ${ }^{2,5-9,13}$ Some researchers have explored another division of Maslow's hierarchy of needs to explain the continued achievement gap. ${ }^{14,15}$ Maslow's theory states, once the physiological needs of an individual are met they are then motivated by the promise of belonging. ${ }^{11}$ Humans are social creatures who seek acceptance from those around them. However, students from impoverished backgrounds often find the values of their social and family group dynamics may not align with the objectives of educators. ${ }^{11,14,15}$ Thus, educational research has explored avenues to help students feel motivated in school through the fostering of a drive for social belonging. ${ }^{11,15}$ Pitzer and Skinner ${ }^{14}$ found when impoverished students engaged in extracurricular activities at school, their academic achievement increased as compared with disadvantaged students who did not partake in these activities. Williams, Bryan, Morrison and Scott ${ }^{15}$ theorized that engagement in such activities created a protective social factor for students and met their need to belong by creating values aligned with educational objectives. Students who engaged in extracurricular activities were also met with an academic responsibility to maintain a certain level of academic performance, such as a prescribed grade point average. ${ }^{14-16}$ This additional responsibility forced all students in the extracurricular activity, such as a sports team, to work towards the same goals as their economically stable counterparts. ${ }^{14-16}$ Furthermore, a fear of social rejection is also speculated to help students maintain the motivation needed in academics to meet the objective. ${ }^{14-16}$ However, the belonging generated by extracurricular activities and the reduced physiological anguish offered by school meal programs have not gone far enough to close the achievement gap for disadvantaged students. ${ }^{2,5-7,9}$ Researchers and practitioners must then explore other factors to help all students achieve at high levels.

\section{Biology and poverty}

The biological perspective offers some added insight into the phenomena of low academic achievement for economically disadvantaged students. ${ }^{17}$ found growing up in poverty was associated with structural differences in the brain. Impoverished students had reduced gray matter in the frontal and temporal lobes as well as the hippocampus, when compared with economically stable students. ${ }^{17}$ The volumes of gray matter were further reduced when disaggregated by the amount of poverty the child endured. Students whose economic means equated to 1.5 times the federal poverty level had a three to four-point reduction in gray matter. ${ }^{17}$ This reduction was more than double for students living below the federal poverty level. ${ }^{17}$ These findings emphasize, the environmental circumstances of poverty have detrimental developmental impacts. These physical changes in the brain may account for the increased mental health and behavioral problems faced by impoverished individuals. ${ }^{18-20}$ 


\section{Poverty and behavior}

Impoverished students were more likely to engage in problem behaviors when they had faced poverty for long periods during development. ${ }^{19}$ In addition, Mazza, Lambert, Zunzunegui, Tremblay, Boivin, and Cote, ${ }^{19}$ asserted students were at greater risk for physical aggression throughout their lives when they lived in poverty between the ages of birth to three years. These increased behavioral occurrences also have a negative impact on student performance. ${ }^{21}$ Students with greater behavioral occurrences spend more in-school time, outside the classroom, as educators seek corrective action such as sending students to the principal's office, detention and even school suspensions. ${ }^{21}$ Continued negative interactions between teachers and student problem behaviors also have a negative impact on the student-teacher relationship. ${ }^{21}$ These relationships have been found to be essential to fostering a sense of belonging and student motivation. ${ }^{11,14,15}$ Additional research has identified teacher-student relationships as necessary for the healthy psychosocial development of students. ${ }^{21-31}$ However, these developments are undermined when teachers regularly intervene with behavioral occurrences. ${ }^{21}$ Despite the major risk factors of poverty to development and social skills, not all impoverished students engage in behavioral issues. Psychosocial factors seem to play an essential role in protecting student academic achievement despite social stratification issues. ${ }^{13,22-24,26-31}$

\section{Development as a protective factor}

Erikson $^{32}$ emphasized that relationships help foster healthy development for all students. However, the trend in research has been to explore only facets of psychosocial development rather than to explore the application of psychosocial development and its relationship to student achievement. Erikson ${ }^{32}$ identified all individuals develop through specific stages starting in infancy. At each state of psychosocial development an individual is faced with a dilemma they must master to develop on to the next stage. The stages from infancy to school age are Trust versus Mistrusts, which occurs in infancy, and Autonomy versus Shame and Doubt which develops during the toddler period. The preschool stage is devoted to the development of Initiative versus Guilt, and finally school age children must learn Industry over Inferiority. Failure to attain in one stage leads the individual to face an identity crisis and causes impairments in the subsequent stages. ${ }^{32}$ Previous research has found that through proper stage attainment individuals gain emotional, social and mental well-being. ${ }^{22-28,31,33-35}$ Stages are either attained or unsuccessful through the dynamic push and pull of interpersonal relationships and psychological developments, hence the term "psychosocial development". ${ }^{32}$ Caregivers must consistently meet physiological needs such as feeding and changing early in development and then encourage autonomous actions such as walking, changing, and toileting. ${ }^{32}$ These feats help children to develop security in their ability and pursue social and academic activities. ${ }^{32}$ Successful relationships have been shown to improve and even predict academic performance. $22-28,31,33-35$

Researchers have also found that development of certain psychosocial characteristics have a major impact on academic performance. Many researchers found motivation plays a vital role in academic performance. ${ }^{11,34}$ Erikson identified through healthy development individuals develop initiative to learn and create personal motivation or the individual is left to flounder in a sense of guilt. ${ }^{32}$ Prosocial behavior was found to have a significant impact on academic achievement. Early prosocial skills were found to be predictive of later academic outcomes. ${ }^{22,27,31,36} \operatorname{Potter}^{38}$ found that levels of psychosocial well-being decrease when an individual's parents' divorce. This reduction of psychosocial well-being correlated with a reduction in academic achievement. ${ }^{38}$ Jones $^{39}$ also found that student interest in or use of drugs in third grade correlated with a reduction in psychosocial stage development when compared to peers who did not show an interest in substances. Jones ${ }^{39}$ postulated that those students who did not have an interest in drugs had developed resiliency. Research has found resiliency to be a vital protective factor for school performance despite potential risk factors to academic performance. ${ }^{40,41}$ Self-regulation skills were also found to provide security to student success despite imperfect circumstances such as growing up in poverty. ${ }^{42}$ Due to this knowledge most of the research has focused on the school-based interpersonal relationship needed to develop these essential protective features: the student-teacher relationship. ${ }^{13,23,28-30}$ Positive student-teacher relationships have been found to be vital to student success; students in these environments are more engaged and motivated to learn than counterparts who may struggle to form healthy student-teacher connections. ${ }^{23,29,30}$

\section{Conclusion}

Social stratification has a significant impact on child development and student potential. Poverty impacts student motivation, biological structures of the brain and child behaviors..$^{14,15,17,19}$ These factors have significant effects on student's ability to attain academically and have successful peer and teacher-student relationships. Research efforts thus far have sought to understand this problem through reactive methods such as school lunch programs and extra-curricular programs which capitalize on Maslow's hierarchy of needs model. Previous research has identified protective factors of interpersonal relationships and psychosocial factors. Further research is needed to effectively understand the developmental milestones which may protect impoverished children and predict achievement from the serious hazards of growing up in poverty. ${ }^{43-47}$

\section{Acknowledgments}

None.

\section{Conflicts of interest}

Author declares that there is no conflicts of interest.

\section{References}

1. Doob, C. Social Inequality and Social Stratification in US Society, Abingdon: Routledge. 2012.

2. Esping-Andersen G. Welfare regimes and social stratification. Journal of European Social Policy. 2015;25(1):124-134.

3. Marginson S. The worldwide trend to high participation higher education: dynamics of social stratification in inclusive systems. Higher Education. 2016;72(4): 413-434.

4. Glatthorn, Boschee, Whitehead et al. Curriculum Leadership: Strategies for development and Implementation. Thousand Oaks: Sage Publications. 2016.

5. Barton P, Coley R. The black-white achievement gap: When progress stopped. Princeton, NJ: ETS Policy Information Center. 2010.

6. Blank RK. Science instructional time is declining in elementary schools: what are the implications for student achievement and closing the gap? Science Education. 2013;97(6):830-847.

7. Hannum E, Hu LC. Chronic undernutrition, short-term hunger, and student functioning in rural northwest China. International Journal of Educational Development. 2017;54:26-28. 
8. Obed N, Ault CR, Bentz B, et al. The black - white "achievement gap" as a perennial challenge of urban science education: A sociocultural and historical overview with implications for research and practice. Journal of Research in Science Teaching. 2001;38 (10):1101-1114.

9. Provosnik S, Gonzales P, Miller D. U.S. performance across international assessments of student achievement. Special supplement to the condition of education 2009 (NCES 2009-083). Washington, DC: National Center for Education Statistics, Institute of Education Sciences, U.S. Department of Education. 2009.

10. Marchetti R, Wilson RH, Dunham M. Academic achievement and extracurricular school activities of at-risk high school students. Educational Research Quarterly. 2016;39(4):3.

11. Maslow AH. A theory of human motivation. Psychological Review. 1943;50(4):370-396.

12. Payne-Sturges DC, Tjaden A, Caldeira KM, et al. Students hunger on campus food insecurity among college students and implications for academic institutions. American Journal of Health Promotion. 2018;32(2):349-354.

13. Fiaschetti CF, Slate JR. Differences in student achievement by grade span configuration for students who were economically disadvantaged. Journal of Education Research. 2014;8(4):221-229.

14. Pitzer J, Skinner E. Predictors of changes in students' motivational resilience over the school year. International Journal of Behavioral Development. 2016;41(1):15.

15. Williams JM, Bryan J, Morrison S, et al. Protective Factors and Processes Contributing to the Academic Success of Students Living in Poverty: Implications for Counselors. Journal of Multicultural Counseling and Development. 2017;45(3):183-200.

16. Bakoban RA, Aljarallah SA. Extracurricular activities and their effect on the students' grade point average: statistical study. Educational Research and Reviews. 2015;10(20):2737-2744.

17. Hair NL, Hanson JL, Wolfe BL, et al. Association of child poverty, brain development, and academic achievement. JAMA pediatrics. 2015;169(9):822-829.

18. Kohrt BA, Jordans MJ, Koirala S, et al. Designing mental health interventions informed by child development and human biology theory: A social ecology intervention for child soldiers in Nepal. Am J Hum Biol. 2015;27(1):27-40.

19. Mazza JR S, Lambert J, Zuzunegui MV, et al. Early adolescence behavior problems and timing of poverty during childhood: A comparison of Life course models. Soc Sci Med. 2017;177:35-42.

20. Russell G, Ford T, Rosenberg R, et al. The association of attention deficit hyperactivity disorder with socioeconomic disadvantage: alternate explanations and evidence. J Child Psychol Psychiatry. 2014;55(5):436445 .

21. McGrath KF, Van Bergen P. Who, when, why and to what end? Students at risk of negative student-teacher relationships and their outcomes. Educational Research Review. 2015;14:1-17.

22. Caprara GV, Barbaranelli C, Pastorelli C, et al. Prosocial foundations of children's academic achievement. Psychological Science. 2000;11(4):302-306.

23. Cappella E, Hamre BK, Kim HY, et al. Teacher consultation and coaching within mental health practice: Classroom and child effects in urban elementary schools. J Consult Clin Psychol. 2012;80(4):597-610.

24. Casillas A, Robbins S, Allen J, et al. Predicting early academic failure in high school from prior academic achievement, psychosocial characteristics, and behavior. Journal of Educational Psychology. 2012;104(2):407-420.

25. Dixson DD, Roberson CCB, Worrell FC. Psychosocial keys to African
American achievement? examining the relationship between achievement and psychosocial variables in high achieving African Americans. Journal of Advanced Academics. 2017;28(2): 120-140.

26. Guzman MP. Mental health matters in elementary school: First-grade screening predicts fourth grade achievement test scores. Eur Child Adolesc Psychiatry. 2011;20(8):401-411.

27. Hall GE, DiPerna JC. Childhood social skills as predictors of middle school academic adjustment. The Journal of Early Adolescence. 2017;37(6):825-851.

28. Imber S. Relationship of trust to academic performance. Journal of Personality and Social Psychology.1973;28 (1):145-150.

29. Maldonado-Carreno C, Votruba-Drzal E. Teacher-child relationships and the development of academic and behavioral skills during elementary school within- and between- child analysis. Child Development. 2011;82(2):601-616.

30. Mason BA, Hajovsky DB, McCune LA, et al. Conflict, closeness, and academic skills: A longitudinal examination of the Teacher-Student relationship. School Psychology Review. 2017;46(2):177-189.

31. VanSchyndel SK, Eisenberg N, Valiente C, et al. Relations from temperamental approach reactivity and effortful control to academic achievement and peer relations in early elementary school. Journal of Research in Personality. 2017;67:15-26.

32. Erikson E H. Identity and the life cycle. New York: W.W Norton \& Company. 1994.

33. Arbabisarjou A, Zare S, Shahrakipour M, et al. Relationship between self-efficacy and academic achievement of zahedan medical sciences students in 2016. International Journal of Medical Research and Health Sciences. 2016;5(7S):349-353.

34. Oga-Baldwin WQ, Nakata Y, Parker P, et al. Motivating young language learners: A longitudinal model of self-determined motivation in elementary school foreign language classes. Contemporary Educational Psychology.2017;49:140-150.

35. Ritchotte JA, Suhr D, Alfurayh NF, et al. An exploration of the psychosocial characteristics of high achieving students and identified gifted students: implication for practice. Journal of advanced academics. 2016;27(1):23-28.

36. Corcoran RP, Cheung A, Kim E, et al. Effective Universal schoolbased social and emotional learning programs for improving academic achievement: A systematic review and meta-analysis of 50 years of research. Educational Research Review. 2017;25:56-72.

37. Jones SM, Barnes SP, Bailey R, et al. Promoting social and emotional competencies in elementary school. The Future of Children. 2017;27(1):49-72.

38. Potter D. Psychosocial well-being and the relationship between divorce and children's academic achievement. Journal of Marriage and Family. 2010;72(4):933-946.

39. Jones R M. Psychosocial development and first substance use in third and fourth grade students: a short-term longitudinal study. Child Development Research. 2010;2011:1-6.

40. Willson VL, Hughes JN. Who is retained in first grade? A psychosocial perspective. Elem Sch J. 2009;109(3):251-266.

41. Young JL, Feille KK, Young JR. Black girls as learners and doers of science: A single-group summary of elementary science achievement. Electronic Journal of Science Education. 2017;21(2):1-20.

42. Kitsantas A, Steen S, Huie, F. The role of self-regulated strategies and goal orientation in predicting achievement of elementary school children. International Electronic Journal of Elementary Education. 2009;2(1):65-81. 
43. Girden ER, Kabacoff RI. Evaluating research articles from start to finish. Thousand Oaks: Sage Publications. 2011.

44. Maine Department of Education. Maine assessment and accountability reporting system. Retrieved from Maine Department of Education. 2017.

45. Tennant JE, Demaray MK, Malecki CK, et al. Students' ratings of teacher support and academic and social-emotional well-being. Sch Psychol $Q$. 2015;30(4):494-512.
46. Thomasian J. Building a science, technology, engineering, and math education agenda: An update of state actions. National Governors Association Center for Best Practices. 2011.

47. US Department of Education. A blueprint for reform: The reauthorization of the Elementary and Secondary Education Act. Washington, DC: Office of Planning, Evaluation, and Policy Development. 2010. 